\title{
PENERAPAN METODE PROMETHEE PADA APLIKASI PERIZINAN DI DINAS KOMUNIKASI DAN INFORMATIKA KOTA TASIKMALAYA
}

\author{
Lucky Hermawan Roza ${ }^{1}$, Acep Irham Gufroni ${ }^{2}$, Rianto $^{3}$ \\ Teknik Informatika, Fakultas Teknik, \\ Universitas Siliwangi \\ Lucky.hermawan.roza14@ student.unsil.ac.id, acep.irham@unsil.ac.id, rianto@unsil.ac.id
}

\begin{abstract}
ABSTRAK
Dalam proses perkembangan teknologi informasi dan komunikasi, menjadi sangat penting bagi suatu organisasi perangkat daerah memiliki sistem yang dapat menunjang pemberian informasi kepada masyarakat dan menjadi salah satu tugas Dinas Komunikasi dan Informatika untuk menyeleksi sistem yang bisa dipublikasikan kepada masyarakat. Tujuan dari penelitian tugas akhir ini adalah membuat sistem perizinan pengembangan aplikasi dengan menggunakan metode PROMETHEE untuk menentukan ranking setiap permohonan yang masuk dan akan di proses oleh petugas Diskominfo dari ranking teratas. PROMETHEE adalah suatu metode penentuan urutan (prioritas) dalam analisis multi kriteria yang menawarkan kesederhanaan, kejelasan, dan kestabilan dalam proses analisisnya. Hasil dari penelitian ini yaitu dalam sistem layanan perizinan pengembangan aplikasi hasil perbandingan antara penentuan prioritas perizinan berdasarkan sistem menggunakan metode PROMETHEE dengan hasil penentuan berdasarkan perhitungan menggunakan Microsoft Excel terhadap 4 data uji maka diperoleh 4 data urutan pemohon pengembangan aplikasi dengan urutan yang sama. Dari hasil pengujian diatas dapat disimpulkan bahwa tidak ada perbedaaan yang signifikan antara hasil penentuan sistem menggunakan metode PROMETHEE dengan hasil penentuan menggunakan Microsoft Excel. Berdasarkan pengujian yang dilakukan ini diharapkan mampu membantu pihak Dinas Komunikasi dan Informatika dalam memutuskan prioritas pemohon yang harus di proses terlebih dahulu terutama dalam hal mengefisiensikan waktu dan untuk mengindari human error dalam penentuan prioritas perizinan pengembangan aplikasi.
\end{abstract}

Kata kunci: metode promethee, pengembangan aplikasi,sistem perizinan.

\begin{abstract}
In the process of developing information and communication technology, it becomes very important for a regional apparatus organization to have a system that can support the provision of information to the community and become one of the tasks of the Communication and Information Agency to select systems that can be published to the public. The purpose of this thesis research is to make an application development licensing system using the PROMETHEE method to determine the ranking of each incoming application and will be processed by Diskominfo officers from the top ranking. PROMETHEE is a method of determining the order (priority) in a multi-criteria analysis that offers simplicity, clarity, and stability in the analysis process. The results of this study are in the application development licensing service system the results of the comparison between the determination of licensing priorities based on the system using the PROMETHEE method with the results of the determination based on calculations using Microsoft Excel against 4 test data then obtained 4 sequence data application applicant development in the same order. From the test results above it can be concluded that there is no significant difference between the results of the determination of the system using the PROMETHEE method with the results of the determination using Microsoft Excel. Based on this test, it is expected to be able to assist the Office of Communication and Information in deciding the priority of the applicant that must be processed first, especially in terms of time efficiency and to avoid human error in determining the application development licensing priorities.

Kata kunci: promethee method, application development, licensing system.
\end{abstract}




\section{PENDAHULUAN}

Pelayanan perizinan dan non perizinan merupakan salah satu pelayanan publik yang disediakan oleh pemerintah sebagai upaya pemenuhan kebutuhan masyarakat. Sejalan dengan perkembangan teknologi informasi, pelayanan publik didukung oleh berbagai aplikasi dan sistem yang tersedia.

Dinas Komunikasi dan Informatika Kota Tasikmalaya merupakan salah satu dinas pelayanan publik yang memberikan pelayanan perizinan pengembangan aplikasi di wilayah Kota Tasikmalaya. Sebagaimana dalam peraturan Walikota Tasikmalaya Nomor 68 Tahun 2016 yang didalam nya membahas tugas Dinas Komunikasi dan Informatika yaitu mengoordinasikan pengembangan layanan publik secara online dan terintegrasi

Dinas Komunikasi dan Informatika melakukan inovasi dengan membuat sebuah sistem perizinan yang berfungsi untuk melakukan pengajuan izin secara online sehingga proses permohonan izin dapat dimonitoring dengan baik.

Dalam penelitian ini menggunakan metode PROMETHEE sebagai sistem pendukung keputusan untuk menentukan prioritas permohonan perizinan karena hasil dari perhitungan dengan menggunakan metode PROMETHEE dapat lebih akurat dibanding dengan menggunakan metode multi kriteria yang lain seperti metode TOPSIS. dalam penelitian Nur, Muhammad (2014) "Studi Komparasi Metode Promethee Dan Topsis Untuk Memberikan Solusi Terbaik Dalam Pengambilan Keputusan Menentukan Tingkat Obesitas" hasil dari penelitian tersebut tingkat keakuratan dengan menggunakan metode PROMETHEE lebih tinggi yaitu 97\%, dibanding dengan menggunakan Metode TOPSIS dengan tingkat keakuratan $87 \%$.

\section{METODE PENELITIAN}

Metode penelitian dalam Pengembangan sistem layanan perizinan pengembangan aplikasi. Terbagi dalam beberapa tahapan yang dapat dilihat pada gambar 1 berikut ini:

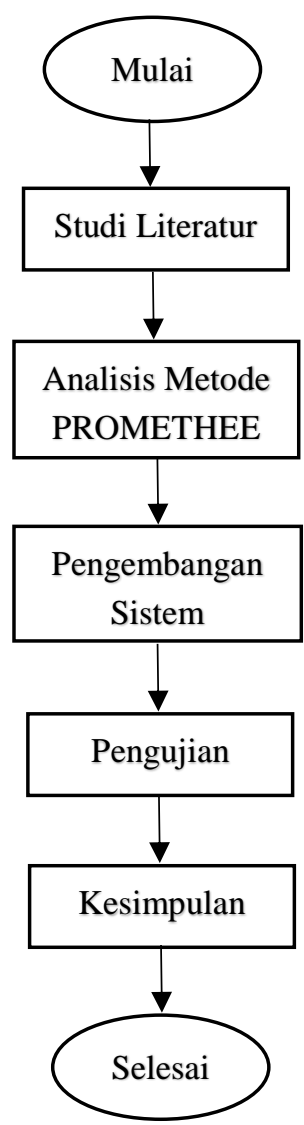

Gambar 1 Alur Metode Penelitian

\section{Studi Literatur}

Studi literatur pada penelitian ini dilakukan dengan cara mencari referensi dari buku-buku atau jurnal yang hamper mendekati dengan penelitian yang dilakukan dan melakukan wawancara beberapa kali ke tempat studi kasus untuk memperoleh datadata yang di perlukan. 


\section{Analisis Metode PROMETHEE}

Metode Promethee digunakan dalam penelitian ini karena metode ini cukup baik dalam memperhitungkan karakteristik dari data. Karena suatu data tidak selamanya bersifat high better atau smaller better, namun lebih ke optimal is better (bukan yang makin besar atau kecil yang terbagus). Pada metode Promethee menyediakan banyak fungsi yang dapat mengakomodasi berbagai karakteristik data. Berikut adalah tabel bobot kriteria dan tabel kriteria yang telah di tentukan :

Tabel 1. Bobot Nilai Kriteria

\begin{tabular}{ccc}
\hline No. & Bobot & Kriteria \\
\hline 1. & 5 & $>91$ \\
2. & 4 & $81-90$ \\
3. & 3 & $71-80$ \\
4. & 2 & $61-70$ \\
5. & 1 & $<90$ \\
\hline
\end{tabular}

Tabel 2. Kriteria Data

\begin{tabular}{llc}
\hline No. & Kriteria & Simbol \\
\hline 1. & $\begin{array}{l}\text { Print out dokumen KAK } \\
\text { (Kerangka Acuan Kerja) }\end{array}$ & $\mathrm{f} 1$ \\
2. & $\begin{array}{l}\text { Keperluan data dalam } \\
\text { pembangunan aplikasi }\end{array}$ & $\mathrm{f} 2$ \\
3. & $\begin{array}{l}\text { Data yang dihasilkan oleh } \\
\text { aplikasi }\end{array}$ & $\mathrm{f} 3$ \\
4. & $\begin{array}{l}\text { Apakah sudah sesuai } \\
\text { dengan TUPOKSI (Tugas }\end{array}$ & $\mathrm{f} 4$ \\
& $\begin{array}{l}\text { Pokok dan Fungsi) pihak } \\
\text { pemohon } \\
\text { Target pembangunan } \\
\text { aplikasi (Tahun } \\
\text { Pengerjaan) }\end{array}$ & $\mathrm{f} 5$ \\
\hline
\end{tabular}

\section{Arsitektur Sistem}

Dalam membangun sistem layanan perizinan dengan menggunakan metode PROMETHEE, diperlukan arsitektur sistem seperti pada gambar 2 berikut ini.

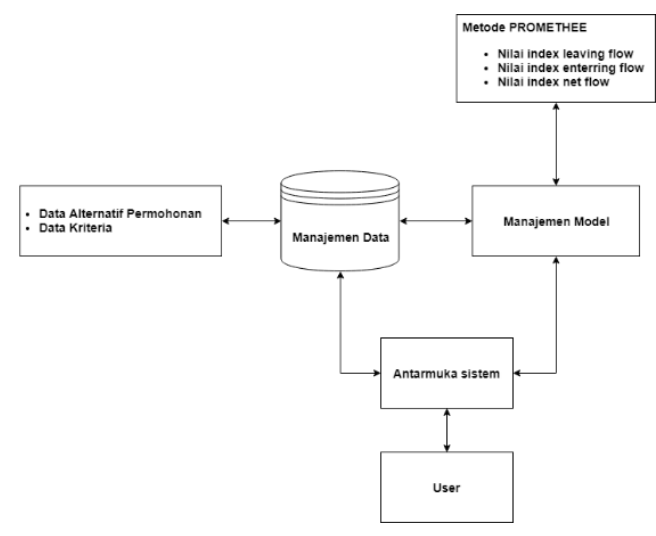

Gambar 2 Arsitektur Sistem

Arsitektur sistem di atas meliputi manajemen data dengan menggunakan Database Management System (DBMS), manajemen model dengan menggunakan metode PROMETHEE dan antarmuka sistem yang digunakan untuk menghubungkan pengguna dengan aplikasi.

\section{Pengembangan Sisten}

Pada penelitian ini, digunakan Extreme Programming (XP) sebagai metode pengembangan software. XP menggunakan bentuk sederhana dari perencanaan dan menganalisis untuk memutuskan apa yang harus dilakukan selanjutnya dan bersifat responsif bila ada fitur yang akan dikembangkan pada masa yang akan datang sebagai perkembangan keinginan pengguna. XP digunakan saat mengembangkan aplikasi yang berpusat pada pengguna dan digunakan oleh tim kecil.

\section{Gambaran Umum UML}

Diagram UML (Unified Modeling Language) yang digunakan dalam merancang sistem terdiri dari use case diagram, dan class diagram. Pada use case diagram, user OPD yang dimaksud adalah user yang akan mengajukan permohonan pengembangan aplikasi. 
(1) Use Case Diagram

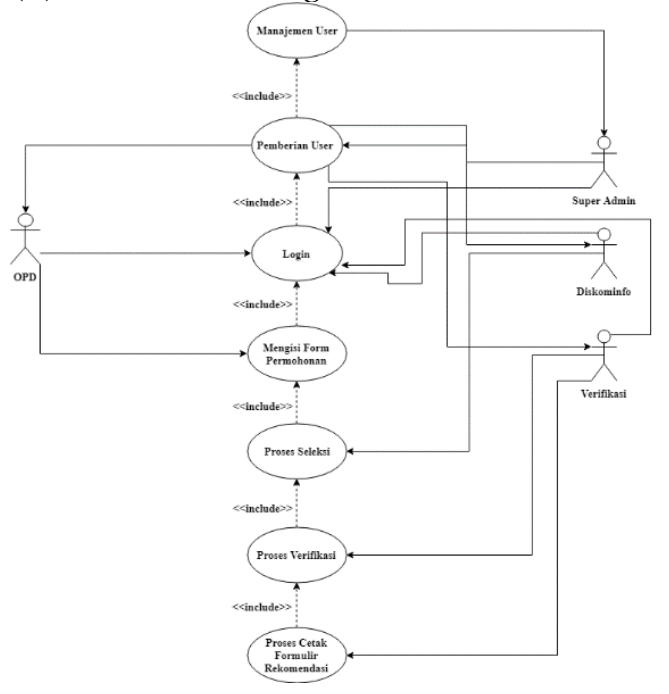

Gambar 3 Use Case Diagram

Pada Use Case Diagram dijelaskan Alur dari Sistem Layanan Perizinan yang terdiri dari empat user yaitu, user OPD, user Admin, user Diskominfo dan user Verifikasi.

\section{(2) Class Diagram}

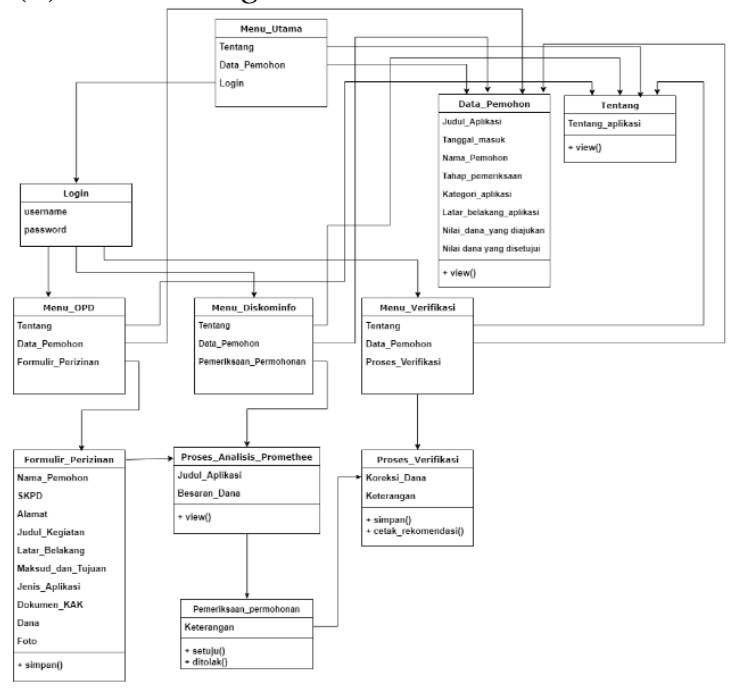

Gambar 4 Class Diagram Sistem Layanan Perizinan
Pemeriksaan_Permohonan, dan Proses_Verifikasi yang relasinya dijelaskan pada gambar diatas.

\section{HASIL DAN PEMBAHASAN}

\section{Sistem Pendukung Keputusan PROMETHEE}

Langkah penyelesaian layanan Perizinan pengembangan aplikasi dengan metode sistem pendukung pengambilan keputusan Preference Ranking Organization Method for Enrichment Evaluation (PROMETHEE). (Sari, Nangi, \& Ramadhan, 2016)

Dalam melakukan penentuan prioritas permohonan perlu adanya suatu penilaian dalam menentukan nilai di setiap aspek, dalam model ini menggunakan pembobotan di setiap subkriteria pada masing masing kriteria. Adapun bobot nilai ditunjukkan pada Tabel 1 dan Kriteria aspek penilaian ditunjukkan pada Tabel 2.

Penilaian kriteria dimaksud untuk memberi nilai atau bobot kepentingan pada kriteria yang dimiliki pemohon. Jumlah data sampel yang digunakan terdiri dari 5 data seperti yang ditunjukkan pada Tabel 3

Tabel 3. Bobot Kriteria Tiap Alternatif

\begin{tabular}{l|c|cccc}
\hline \multirow{2}{*}{ No. } & \multirow{2}{*}{ Kriteria } & \multicolumn{5}{|c}{ Nilai Alternatif } \\
\cline { 3 - 6 } & & A & B & C & D \\
\hline 1 & f1 & 4 & 4 & 5 & 5 \\
2 & f2 & 4 & 3 & 4 & 3 \\
3 & f3 & 1 & 2 & 4 & 3 \\
4 & f4 & 3 & 4 & 5 & 3 \\
5 & f5 & 3 & 5 & 1 & 4 \\
\hline \multicolumn{2}{l}{ Jumlah Nilai } & 15 & 18 & 19 & 18 \\
\hline
\end{tabular}

Sistem Layanan Perizinan yang dirancang memiliki beberapa class antara lain Menu_utama, Login, Data_Pemohon, Tentang, Menu_OPD, Menu_Diskominfo, Menu_Verifikasi, Formulir_Perizinan,

Penerapan Metode Promethee Pada Aplikasi Perizinan Di Dinas Kominikasi Dan Informatika Kota Tasikmalaya| 77 
Selanjutnya melakukan perhitungan penerapan metode PROMETHEE untuk menentukan prioritas permohonan.

(1) Menghitung Selisih Nilai Antar Alternatif Terhadap Kriteria Tertentu

Perhitungan selisih nilai kriteria (d) antar alternatif dilakukan dengan membandingkan satu alternatif dengan alternatif lainnya dengan cara mengurangkan nilai alternatif a dengan alternatif $b$, kemudian dihitung nilai fungsi preferensinya $H(d)$ sesuai dengan fungsi preferensi yang digunakan. Untuk perhitungan lebih lengkapnya, ditunjukkan oleh

Tabel 4. Bobot Kriteria Tiap Alternatif

\begin{tabular}{|c|c|c|c|c|}
\hline Alternatif & $\mathbf{A}$ & B & $\mathrm{C}$ & D \\
\hline $\mathbf{A}$ & - & $\begin{array}{l}\mathrm{f} 1=0, \\
\mathrm{f} 2=1, \\
\mathrm{f} 3=0, \\
\mathrm{f} 4=0, \\
\mathrm{f} 5=0\end{array}$ & $\begin{array}{l}\mathrm{f} 1=0, \\
\mathrm{f} 2=0, \\
\mathrm{f} 3=0, \\
\mathrm{f} 4=0, \\
\mathrm{f} 5=1\end{array}$ & $\begin{array}{l}\text { f1 }=0, \\
\text { f2 }=1, \\
\text { f3 }=0, \\
\text { f4 }=1, \\
\text { f5 }=0\end{array}$ \\
\hline B & $\begin{array}{l}\mathrm{f} 1=0, \\
\mathrm{f} 2=0, \\
\mathrm{f} 3=1, \\
\mathrm{f} 4=1, \\
\mathrm{f} 5=1\end{array}$ & - & $\begin{array}{l}\mathrm{f} 1=0, \\
\mathrm{f} 2=0, \\
\mathrm{f} 3=0, \\
\mathrm{f} 4=0, \\
\mathrm{f} 5=1\end{array}$ & $\begin{array}{l}\mathrm{f} 1=0, \\
\mathrm{f} 2=0, \\
\mathrm{f} 3=0, \\
\mathrm{f} 4=1, \\
\mathrm{f} 5=1\end{array}$ \\
\hline C & $\begin{array}{l}\mathrm{f} 1=1, \\
\mathrm{f} 2=0, \\
\mathrm{f} 3=1, \\
\mathrm{f} 4=1, \\
\mathrm{f} 5=0\end{array}$ & $\begin{array}{l}\mathrm{f} 1=1, \\
\mathrm{f} 2=1, \\
\mathrm{f} 3=1, \\
\mathrm{f} 4=1, \\
\mathrm{f} 5=0\end{array}$ & & $\begin{array}{l}\mathrm{f} 1=0, \\
\mathrm{f} 2=1, \\
\mathrm{f} 3=1, \\
\mathrm{f} 4=1, \\
\mathrm{f} 5=0\end{array}$ \\
\hline D & $\begin{array}{l}\mathrm{f} 1=1, \\
\mathrm{f} 2=0, \\
\mathrm{f} 3=1, \\
\mathrm{f} 4=0, \\
\mathrm{f} 5=1\end{array}$ & $\begin{array}{l}\mathrm{f} 1=1, \\
\mathrm{f} 2=0, \\
\mathrm{f} 3=1, \\
\mathrm{f} 4=0, \\
\mathrm{f} 5=0\end{array}$ & $\begin{array}{l}\mathrm{f} 1=0, \\
\mathrm{f} 2=0, \\
\mathrm{f} 3=0, \\
\mathrm{f} 4=0, \\
\mathrm{f} 5=1\end{array}$ & - \\
\hline
\end{tabular}

(2) Menghitung Indeks Preferensi

Multikriteria Indeks preferensi multikriteria ditentukan berdasarkan ratarata bobot dari fungsi prefrerensi. Tabel 5 menunjukkan indeks preferensi multikriteria. Dan berikut adalah perhitungan index preferensi mutikriteria

$(\mathrm{A}, \mathrm{B})=(0+1+0+0+0) / 5=1 / 5=0,2$

$(\mathrm{B}, \mathrm{A})=(0+0+1+1+1) / 5=3 / 5=0,6$

$(\mathrm{A}, \mathrm{C})=(0+0+0+0+1) / 5=1 / 5=0,2$

$(\mathrm{C}, \mathrm{A})=(1+0+1+1+0) / 5=3 / 5=0,6$

$(\mathrm{A}, \mathrm{D})=(0+1+0+1+0) / 5=2 / 5=0,4$

$(\mathrm{D}, \mathrm{A})=(1+0+1+0+1) / 5=3 / 5=0,6$

$(B, C)=(0+0+0+0+1) / 5=1 / 5=0,2$

$(C, B)=(1+1+1+1+0) / 5=4 / 5=0,8$

$(\mathrm{B}, \mathrm{D})=(0+0+0+1+1) / 5=2 / 5=0,4$

$(\mathrm{D}, \mathrm{B})=(1+0+1+0+0) / 5=2 / 5=0,4$

$(\mathrm{C}, \mathrm{D})=(0+1+1+1+0) / 5=3 / 5=0,6$

$(\mathrm{D}, \mathrm{C})=(0+0+0+0+1) / 5=1 / 5=0,2$

Tabel 5. Tabel Indeks Preferensi Multikriteria

\begin{tabular}{c|cccc}
\hline Alternatif & A & B & C & D \\
\hline A & - & 0,2 & 0,2 & 0,4 \\
B & 0,6 & - & 0,2 & 0,4 \\
C & 0,6 & 0,8 & - & 0,6 \\
D & 0,6 & 0,4 & 0,2 & - \\
\hline
\end{tabular}

(3) Menghitung Leaving Flow

Leaving flow adalah jumlah dari yang memiliki arah mendekat dari node a dan hal ini merupakan karakter pengukuran out rangking. Berikut adalah perhitungan Leaving Flow :

$$
\begin{aligned}
\varphi^{+} a=\frac{1}{(4-1)} & (0,2+0,2+0,4) \\
& =\frac{1}{3}(0,8) \\
& =0,26667 \\
\varphi^{+} b=\frac{1}{(4-1)} & (0,6+0,2+0,4) \\
= & \frac{1}{3}(1,2) \\
& =0,4
\end{aligned}
$$

$$
\begin{aligned}
& \begin{aligned}
\varphi^{+} c=\frac{1}{(4-1)} & (0,6+0,8+0,6) \\
& =\frac{1}{3}(2) \\
& =0,66667
\end{aligned} \\
& \varphi^{+} d=\frac{1}{(4-1)}(0,6+0,4+0,2)
\end{aligned}
$$

Penerapan Metode Promethee Pada Aplikasi Perizinan Di Dinas Kominikasi Dan Informatika Kota Tasikmalaya| 78 


$$
\begin{aligned}
& =\frac{1}{3}(1,2) \\
& =0,4
\end{aligned}
$$

(4) Menghitung Entering Flow

Entring Flow adalah jumlah dari yang memiliki arah menjauh dari node a. berikut adalah perhitungan Entering Flow :

$$
\begin{aligned}
\varphi^{-} a=\frac{1}{(4-1)} & (0,6+0,6+0,6) \\
= & \frac{1}{3}(1,8) \\
& =0,6 \\
\varphi^{-} b=\frac{1}{(4-1)} & (0,2+0,8+0,4) \\
& =\frac{1}{3}(1,4) \\
& =0,46667 \\
\varphi^{-} c=\frac{1}{(4-1)} & (0,2+0,2+0,2) \\
& =\frac{1}{3}(0,6) \\
& =0,2 \\
\varphi^{-} d=\frac{1}{(4-1)} & (0,4+0,4+0,6) \\
& =\frac{1}{3}(1,4) \\
& =0,46667
\end{aligned}
$$

(5) Menghitung Net Flow

Rumus yang digunakan untuk mencari Net flow dilihat pada Persamaan. Tabel 4.6 menunjukkan Tabel Ranking Metode PROMETHEE. berikut adalah perhitungan Net Flow:

$$
\begin{aligned}
& \varphi(a)=0,26667-0,6=-0,33333 \\
& \varphi(b)=0,4-0,46667=-0,6667 \\
& \varphi(c)=0,6667-0,2=0,46667 \\
& \varphi(d)=0,4-0,46667=-0,6667
\end{aligned}
$$

Tabel 4. Ranking Metode PROMETHEE

\begin{tabular}{c|lccc}
\hline Alternatif & $\begin{array}{c}\text { Leaving } \\
\text { Flow }\end{array}$ & $\begin{array}{c}\text { Entering } \\
\text { Flow }\end{array}$ & $\begin{array}{c}\text { Net } \\
\text { Flow }\end{array}$ & $\begin{array}{c}\text { Rangki } \\
\text { ng }\end{array}$ \\
\hline A & 0.26667 & 0.6 & -0.33333 & 4 \\
B & 0.4 & 0.46667 & -0.06667 & 3 \\
C & 0.66667 & 0.2 & 0.46667 & 1 \\
\hline
\end{tabular}
D
0.4
$0.46667 \quad-0.06667$
2

\section{Implementasi Aplikasi}

\section{Halaman Dashboard}

Halaman dashboard aplikasi layanan perizinan pembangunan aplikasi ini dapat dilihat pada gambar 6 tampilan utama aplikasi layanan perizinan pembangunan aplikasi.

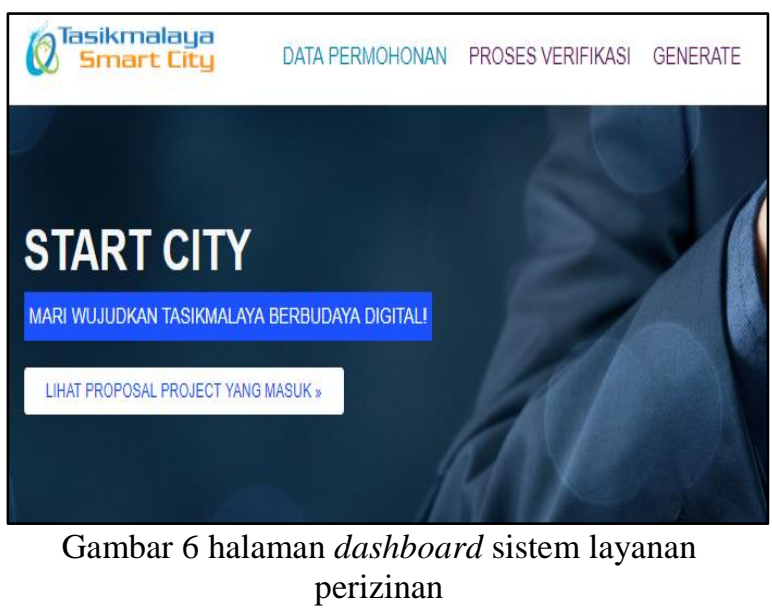

Halaman Generate

Halaman generate dapat dilihat pada gambar 7 dan 8 .

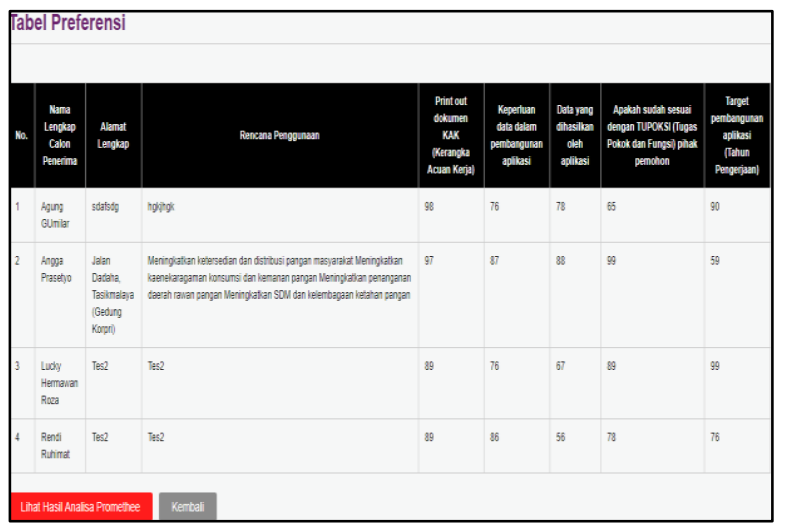

Gambar 7 Halaman Tabel Preferensi

Gambar 7 atau halaman Tabel Preferensi berfungsi untuk menampilkan hasil penilaian setiap kriteria pada setiap permohonan yang sudah di periksa oleh user diskominfo yang

Penerapan Metode Promethee Pada Aplikasi Perizinan Di Dinas Kominikasi Dan Informatika Kota Tasikmalaya| 79 
selanjutnya dapat dilihat hasil analisis promethee nya dengan menekan tombol lihat hasil analisa PROMETHEE.

\section{Halaman Analisa PROMETHEE}

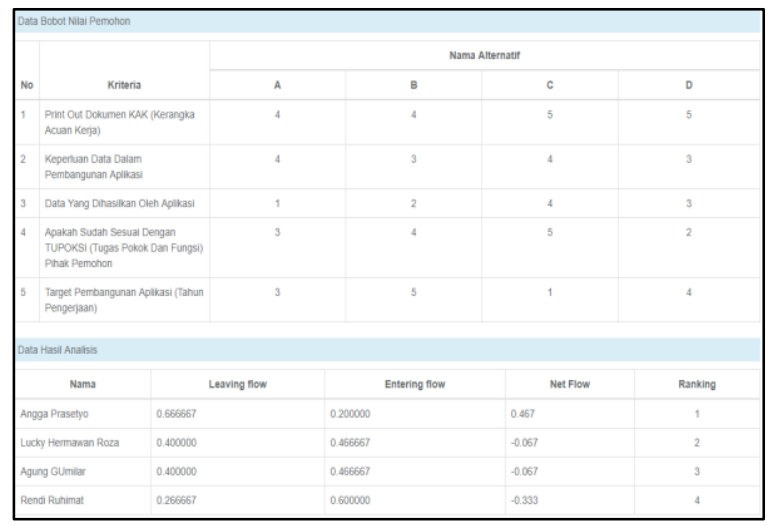

Gambar 8 Halaman hasil analisa PROMETHEE

Gambar 8 merupakan halaman hasil analisa dengan menggunakan metode PROMETHEE dengan mementukan ranking setiap permohonan yang selanjutnya dapat di proses sesuai urutan perankingan.

\section{Pengujian Sistem (System Testing)}

Pengujian metode aplikasi layanan perizinan dengan metode PROMETHEE menggunakan pengujian metode black box dan pengujian perbandingan.

Tabel 6 Pengujian menggunakan metode black-box

\begin{tabular}{|c|c|c|c|c|}
\hline No & $\begin{array}{c}\text { Langkah } \\
\text { Pengujian }\end{array}$ & $\begin{array}{c}\text { Hasil } \\
\text { Yang } \\
\text { Diharap } \\
\end{array}$ & $\begin{array}{c}\text { Hasil } \\
\text { Pengujian }\end{array}$ & $\begin{array}{c}\text { Respon } \\
\text { Program }\end{array}$ \\
\hline 1 & Login & $\begin{array}{l}\text { Berhasil } \\
\text { melakuk } \\
\text { an login }\end{array}$ & $\begin{array}{c}\text { Berhasil } \\
\text { masuk ke } \\
\text { menu }\end{array}$ & berhasil \\
\hline 2 & $\begin{array}{l}\text { Menu } \\
\text { Tentang }\end{array}$ & $\begin{array}{l}\text { Berhasil } \\
\text { masuk } \\
\text { ke menu }\end{array}$ & $\begin{array}{l}\text { Masuk ke } \\
\text { menu } \\
\text { tentang }\end{array}$ & Berhasil \\
\hline 3 & $\begin{array}{l}\text { Menu data } \\
\text { permohon } \\
\text { an }\end{array}$ & $\begin{array}{l}\text { Berhasil } \\
\text { menyimp } \\
\text { an data }\end{array}$ & $\begin{array}{l}\text { Masuk ke } \\
\text { menu data } \\
\text { permohona }\end{array}$ & Berhasil \\
\hline 4 & $\begin{array}{l}\text { Menu } \\
\text { formulir } \\
\text { permohon }\end{array}$ & $\begin{array}{c}\text { Berhasil } \\
\text { menyimp } \\
\text { an data }\end{array}$ & $\begin{array}{c}\text { Data } \\
\text { Permohona } \\
\text { n berhasil }\end{array}$ & Berhasil \\
\hline
\end{tabular}

\begin{tabular}{|c|c|c|c|c|}
\hline 5 & \begin{tabular}{|l|} 
Menu \\
pemeriksa \\
an data
\end{tabular} & $\begin{array}{c}\text { Berhasil } \\
\text { masuk } \\
\text { ke menu }\end{array}$ & $\begin{array}{c}\text { Masuk ke } \\
\text { menu } \\
\text { pemeriksaa }\end{array}$ & Berhasil \\
\hline 6 & $\begin{array}{l}\text { Tombol } \\
\text { proses } \\
\text { pemeriksa }\end{array}$ & $\begin{array}{l}\text { Pindah } \\
\text { ke } \\
\text { halaman }\end{array}$ & $\begin{array}{l}\text { Berhasil } \\
\text { masuk ke } \\
\text { halaman }\end{array}$ & Berhasil \\
\hline 7 & $\begin{array}{l}\text { Menu } \\
\text { proses } \\
\text { pemeriksa }\end{array}$ & $\begin{array}{c}\text { Berhasil } \\
\text { menyimp } \\
\text { an data }\end{array}$ & $\begin{array}{c}\text { Data } \\
\text { pemeriksaa } \\
\mathrm{n}\end{array}$ & Berhasil \\
\hline 8 & $\begin{array}{l}\text { Menu } \\
\text { preferensi }\end{array}$ & $\begin{array}{c}\text { Berhasil } \\
\text { masuk } \\
\text { ke menu }\end{array}$ & $\begin{array}{l}\text { Masuk ke } \\
\text { menu data } \\
\text { preferensi }\end{array}$ & Berhasil \\
\hline 9 & $\begin{array}{l}\text { Tombol } \\
\text { analisa } \\
\text { Promethee }\end{array}$ & $\begin{array}{c}\text { Menamp } \\
\text { ilkan } \\
\text { hasil }\end{array}$ & $\begin{array}{l}\text { Data hasil } \\
\text { analisa } \\
\text { metode }\end{array}$ & Berhasil \\
\hline 10 & $\begin{array}{l}\text { Menu } \\
\text { verifikasi } \\
\text { data }\end{array}$ & $\begin{array}{c}\text { Berhasil } \\
\text { masuk } \\
\text { ke menu }\end{array}$ & $\begin{array}{l}\text { Masuk ke } \\
\text { menu } \\
\text { verifikasi }\end{array}$ & Berhasil \\
\hline 11 & $\begin{array}{l}\text { Tombol } \\
\text { proses } \\
\text { verifikasi }\end{array}$ & $\begin{array}{l}\text { Pindah } \\
\text { ke } \\
\text { halaman }\end{array}$ & $\begin{array}{c}\text { Berhasil } \\
\text { masuk ke } \\
\text { halaman }\end{array}$ & Berhasil \\
\hline 12 & $\begin{array}{l}\text { Proses } \\
\text { verifikasi } \\
\text { data }\end{array}$ & $\begin{array}{c}\text { Berhasil } \\
\text { menyimp } \\
\text { an data }\end{array}$ & $\begin{array}{c}\text { Menyimpa } \\
\text { n data hasil } \\
\text { verifikasi }\end{array}$ & Berhasil \\
\hline 13 & $\begin{array}{l}\text { Menu } \\
\text { koreksi }\end{array}$ & $\begin{array}{c}\text { Berhasil } \\
\text { Mengkor } \\
\text { eksi jika }\end{array}$ & $\begin{array}{l}\text { Mengkorek } \\
\text { si data pada } \\
\text { proses }\end{array}$ & Berhasil \\
\hline 14 & Menu $\mathrm{cms}$ & $\begin{array}{c}\text { Berhasil } \\
\text { menamb } \\
\text { ah, }\end{array}$ & $\begin{array}{l}\text { Menambah } \\
\text { menghapus }\end{array}$ & Berhasil \\
\hline 15 & $\begin{array}{l}\text { Menu } \\
\text { laporan }\end{array}$ & $\begin{array}{c}\text { Berhasil } \\
\text { menamb } \\
\text { ah }\end{array}$ & $\begin{array}{l}\text { Menambah } \\
\text { laporan } \\
\text { data }\end{array}$ & Berhasil \\
\hline 16 & $\begin{array}{l}\text { Menu } \\
\text { Analisa } \\
\text { Promethee }\end{array}$ & $\begin{array}{c}\text { Berhasil } \\
\text { menentu } \\
\text { kan }\end{array}$ & $\begin{array}{c}\text { Menentuka } \\
\text { n ranking } \\
\text { tiap }\end{array}$ & Berhasil \\
\hline
\end{tabular}

\section{Pengujian Perbandingan}

Pengujian perbadingan ini yaitu membandingkan perhitungan metode PROMETHEE dengan menggunakan Microsoft excel dengan aplikasi yang telah dibuat, hasil perbandingan tersebut dapat dilihat pada gambar 9 dan 10 . 


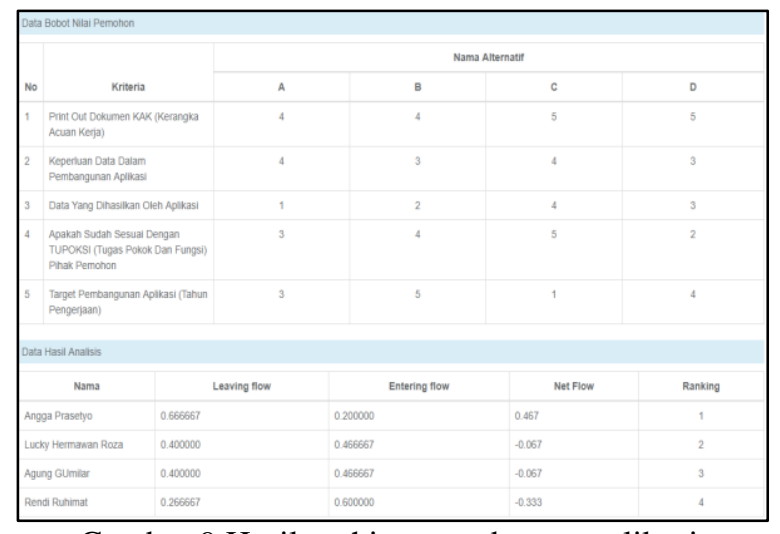

Gambar 9 Hasil perhitungan dengan aplikasi

Pada gambar 9 adalah hasil perhitungan nilai setiap permohonan menggunakan metode PROMETHEE sesuai dengan nilai kriteria yang sudah di tentukan oleh user diskominfo dan output yang dihasilkan berupa nilai Leaving Flow, Entering Flow, Net Flow dan Ranking setiap permohonan.

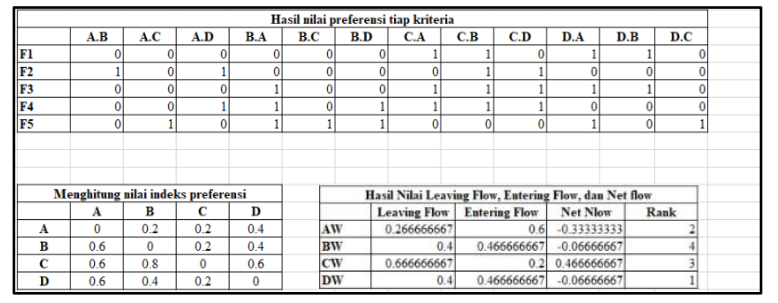

Gambar 10 Hasil perhitungan dengan excel

Dari gambar 10 hasil perhitungan manual menggunakan aplikasi Ms Excel dengan nilai kriteria dan metode yang sama dengan aplikasi yang sudah dibuat. Kesimpulan dari hasil perbandingan kedua perhitungan trersebut dapat menghasilkan output nilai yang sama yaitu permohonan dengan peringkat teratas menghasilkan nilai leaving flow $=0,66667$, entering flow $=0,2$ dan net flow $=0,46667$.

\section{PENUTUP}

\section{Kesimpulan}

Berdasarkan hasil analisis selama melaksanakan penelitian di Dinas Komunikasi dan Informatika yang berjudul
Rancang Bangun Sistem Layanan Perizinan Pengembangan Aplikasi dengan Menggunakan Metode Preference Ranking Organization Method for Enrichment Evaluation (PROMETHEE), dapat disimpulkan bahwa :

1. Telah dibangun sistem layanan perizinan yang dapat digunakan untuk mempermudah pelaksanaan pengawasan dalam pengelolaan infrastruktur TIK.

2. Sistem dapat membatu mempermudah proses pengintegrasian data dari seluruh OPD (Organisasi Perangkat Daerah) di wilayah Kota Tasikmalaya.

3. Dengan menggunakan metode PROMETHEE sistem dapat menentukan prioritas data pemohon yang harus di proses terlebih dahulu sesuai dengan kriteria yang sudah di tentukan.

\section{Saran}

Berikut saran dari penelitian Rancang Bangun Sistem Layanan Perizinan Pengembangan Aplikasi dengan Menggunakan Metode Preference Ranking Organization Method for Enrichment Evaluation (PROMETHEE) :

(1) Untuk pengembangan selanjutnya dapat dibuatkan aplikasi berbasis mobile sehingga pemohon dalam melakukan proses pendaftaran dapat menggunakan smartphone.

(2) Perlu ada pemeliharaan sistem yang baik menyangkut pemeliharaan data, pemeliharaan perangkat pengelolaan data, maupun pemeliharaan aplikasi.

\section{DAFTAR PUSTAKA}

Arsita, R. (2013). Sistem Pendukung Keputusan Penerima Jaminan Kesehatan Masyarakat (Jamkesmas) dengan Metode Promethee (studi kasus: Sari Mandala-I). Journal 
Pelita Informatika Budi Darma, vol: IV nomor 2, Agustus 2013 ISSN: 2301-9425.

Dharwiyanti, S. (2003). Pengantar Unified Modeling Language (UML).

Nugroho, A., \& et.al. (2012). Rekayasa Perangkat Lunak. In R. S. Pressman, Software Engineering : A Practitioner's Approach, Seventh Edition. Yogyakarta: ANDI.

Pratama, E. B. (2017). Pendekatan Metodologi Extreme Programming pada Aplikasi e-Commerce. JURNAL KHATULISTIWA INFORMATIKA, VOL. V, NO. 2.

Rahayu, M. P. (2013). Metodologi Extreme Programming. Retrieved from http://keinatralala.com/2013/12/13/m etodologi-extreme-programming/

Rosa A.S, \& Shalahuddin, M. (2013). Rekayasa Perangkat Lunak Terstruktur dan Berorientasi Objek. Bandung: Informatika Bandung.

Sari, A. S., Nangi, J., \& Ramadhan, R. (2016). Penerapan Metode Promethee Dalam Sistem Penunjang Keputusan Penentuan Penerima Beasiswa Bidik Misi Universitas Halu Oleo. semanTIK, Vol.2, No.2, Jul-Des 2016, pp. 157-166 ISSN: 2502-8928 (Online) .

Sutanta, E. (2014). Sistem Basis Data. Graha Ilmu.

Wiharni, F., Prasetyo, Y. A., \& Adi, T. N. (2016). PENGEMBANGAN MODUL LELANG PADA SIAPSIAPNIKAH.COM
MENGGUNAKAN METODE EXTREME PROGRAMMING DAN KONSEP CROWDSOURCING. Jurnal Rekayasa Sistem \& Industri Volume 3, Nomor 3.

Zulfiandri, Hidayatuloh, S., \& Anas, M. (2014). Rancang Bangun Aplikasi Poliklinik Gigi (Studi Kasus : Poliklinik Gigi Kejaksaan Agung Ri). KOMMIT. 